\title{
Foreword: The military engineer and concrete
}

\section{David W. Pittman}

Director, Geotechnical and Structures Laboratory, Engineer Research and Development Center, US Army Corps of Engineers, Vicksburg, MS, USA

Military organisations have been using concrete as a construction material for centuries. Two thousand years ago, the great Roman armies used early forms of concrete not just for fighting wars, but for building infrastructure within the nations they occupied. Today, military organisations like the US Army Corps of Engineers continue the tradition of building infrastructure to support both military and civil works missions in the USA and overseas. Along the way, the Corps has placed millions of tonnes of concrete and has been instrumental in the development and use of concrete as a construction material worldwide.

The Corps has had a long and rich history as a military and public engineering organisation, tracing its origin to the very beginning of the USA. From its earliest days, it constructed fortifications along the coast of the fledgling country, cleared rivers and waterways of obstructions to support navigation and commerce, and built roads for the ever-expanding country. As the Army's engineer, the Corps has supported the US military in every major war, from the Revolutionary War to the current conflict in Afghanistan, by building fortifications, military installations, airfields, bridges and other infrastructure critical to the war-fighting effort.

The Corps built many of the nation's premier infrastructure projects, including the National Road, the Bonneville dam, the Manhattan Project, the Pentagon, the Kennedy Space Center and the Washington Monument. Today, the Corps maintains direct control of more than 600 dams, 250 navigation locks and 75 hydroelectric facilities, maintains more than 12000 miles $(19000 \mathrm{~km})$ of commercially navigable channels and 300 commercial harbours, and inspects more than 2000 levees across the USA.

The Corps has a large international mission as well, working in more than 90 countries. The Corps supervised the completion of the Panama Canal 100 years ago, helped construct key military facilities in Saudi Arabia during the Cold War and today supports the military construction mission at 250 US Army and Air Force installations around the world.

Most of my 30-year career as an engineer has been spent with the Corps, which has had a long and rich history in concrete materials research to support its military and civil construction programmes. The earliest Corps concrete research laboratory was established in the 1930s in Eastport, Maine, and it has since moved to its current location at the US Army Engineer Research and Development Center (ERDC), in Vicksburg, Mississippi, where I work as the Director of the Geotechnical and Structures Laboratory.

When I began my career at ERDC (formerly the Waterways Experiment Station, or WES) in 1983, my research centred on the use of roller-compacted concrete (RCC) for pavement applications at military installations. I was fortunate to learn under the tutelage of many experts in concrete materials and construction, including Dr Bryant Mather - 'Mr Concrete' to many professionals around the world. My colleagues were responsible for many breakthroughs in concrete technology, creating new knowledge in the understanding of concrete durability, mass concrete properties, the use of recycled and indigenous materials, heavyweight concrete, ultra-high-strength concrete, concrete pavements and RCC, to name a few. We studied the response of concrete structures to blast and weapons effects - to design both structures and materials that could resist those effects and weapons that could defeat them.

We worked in partnership with experts in the construction industry, academia, government and professional societies to produce technical reports, technical manuals, test methods, guide specifications, standard practice manuals, magazine articles and journal articles like those included in the Magazine of Concrete Research. In these and numerous other publications, we shared our knowledge of concrete mixture proportioning, material properties, design, construction and performance for the mutual good.

For 64 years, the Magazine of Concrete Research has provided the results of cutting-edge research to support the ever-growing need for concrete, the most ubiquitous construction material in the world. This themed issue on military concrete presents research that is illustrative of the unique constraints that the military mission sometimes places upon the engineer designer. The military engineer often works in conditions where speed of construction, use of indigenous materials and extreme loading regimes require innovations in concrete design and construction that often carry over into benefits for public and private sector construction as well.

In this issue, a new experimental method of measuring the triaxial properties of concrete under loading is presented, which will be useful in predicting the response of concrete under a variety of loads. This issue also gives a brief history of how the military used 
concrete and how methods and materials were adapted during World War I. Two papers focus on the effects of blast loadings on reinforced concrete structures. One paper evaluates the validity of numerical models that predict the response of structures to blast, and recommends expedient techniques for assessing the blast response of structures. Another paper focuses on an analytical method for assessing the residual strength of reinforced concrete columns subjected to blast loadings. Finally, research from the ERDC outlines new expedient repair methods for concrete airfield pavements that dramatically reduce the time required to reopen an airfield after it has been damaged by bombing.
Recently, I had the privilege of serving with the US ForcesAfghanistan, to assist them in constructing billions of dollars' worth of power, water, transportation and military infrastructure for that war-torn country. The people of Afghanistan were working side by side with soldiers and civilians from many nations. As I watched the Afghan people mix concrete in small drum mixers and transport the freshly mixed material in wheelbarrows to construct foundations for new buildings, I could not help but hope that, with our efforts, a new foundation for the country was being built that would be just as strong and durable as the concrete itself. 